\section{ECONOMICS}

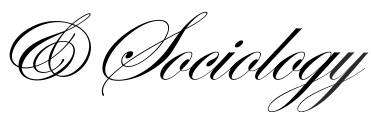

Lewandowska, A., Stopa, M., \& Inglot-Brzęk, E. (2021). Innovativeness and entrepreneurship: socioeconomic remarks on regional development in peripheral regions. Economics and Sociology, 14(2), 222-235. doi:10.14254/2071-789X.2021/14$2 / 12$

\title{
INNOVATIVENESS AND ENTREPRENEURSHIP: SOCIOECONOMIC REMARKS ON REGIONAL DEVELOPMENT IN PERIPHERAL REGIONS
}

\author{
Anna Lewandowska \\ Department of Management, \\ University of Information \\ Technology and Management, \\ Rzeszón, Poland \\ E-mail: \\ alewandowska@wsiz.edu.pl
}

ORCID 0000-0002-5351-8490

\author{
Mateusz Stopa \\ Department of Social Sciences, \\ University of Information \\ Technology and Management, \\ Rzeszón, Poland \\ E-mail:mstopa@.gmail.com \\ ORCID 0000-0002-9286-5073 \\ Elżbieta Inglot-Brzęk \\ Department of Social Sciences, \\ University of Information \\ Technology and Management, \\ Rzeszón, Poland \\ E-mail: \\ elsbietainglot.brzek@gmail.com \\ ORCID 0000-0003-3716-3295
}

Received: April, 2020

1st Revision: June, 2020

Accepted: March, 2021

DOI: $10.14254 / 2071-$

789X.2021/14-2/12

JEL Classification: L26, O31, R58
ABSTRACT. The subject of the article was derived from the learning region theory. The assumption was made that through cooperation of various entities conditions are created conducive to the development of knowledge, entrepreneurship and innovation in regions. The objective is to present the issues of entrepreneurship and innovation as the endogenous factors of regional development in the Podkarpackie region. Empirical conclusions presented in this article come from the research conducted back in 2010-2016. The study is based on the data drawn from CATI carried out among SMEs and qualitative in-depth interviews with "innovation leaders". The results show an important element in the incompatibility between SMEs' investment strategies and the institutional environments that should support SMEs in action and planning. There is an incompatibility between the statistical and the empirical approaches to innovation. Based on the results of the empirical research, we conclude that regional policy, concentrated on only the statistical approach to the subject of entrepreneurship and innovation, is doomed to failure. It should include an empirical (qualitative) approach and the regional specificity, especially within peripheral regions.

Keywords: innovation, SMEs, entrepreneurship, regional development, peripheral region. 


\section{Introduction}

The subject of this article is the issue of innovation in SMEs and entrepreneurship in the context of regional development in the peripheral regions with the specific characteristics of the voivodships of the Eastern Poland, including the Podkarpackie region. Even though SMEs and large companies have different advantages and drawbacks when it comes to innovation, SMEs provide the most conducive environment for entrepreneurship and innovation. The voivodships of the Eastern Poland are less economically developed areas (measured in GDP per capita) with high dependence on agriculture. They are characterized by a low level of human capital (namely, low levels of education and science), limited availability of territorial assets (communications and IT), low level of infrastructure, lowincome levels of the population and capacity of the local government units (Grosse, 2007). Thus, these voivodships can be defined as peripheral regions. According to Braudel's (1960) concept of long-term duration, Wallerstein's (2006) theory of core-periphery and the concept of regional culture, the peripheral character of the region of Eastern Poland will continue. At the same time, innovations implemented by SMEs are the endogenous factors which can stimulate regional development. This is a very interesting case study since it covers the peripheral regions in the peripheral countries, being remote from the traditional European centers of innovations.

The aim of this paper is to find and reveal possible incompatibility between SME investment strategies and the institutional support system in entrepreneurship and innovation context. The research methods adopted for this paper are statistical analysis of the data from CATI carried out among SMEs and qualitative structured individual interviews (in-depth interviews - IDIs) with "innovation leaders".

The paper is organized as follows. The section following this one is a literature review focusing on regional development in its economic perspective followed by a literature review on the peripheral regions in the sociological perspective. The third section presents the methodology and the data collected for this study. The empirical analysis, results, and interpretation of the results are reported in section 4 , followed by the conclusion section.

\section{Literature review}

\subsection{Regional development in economic perspective}

Earlier theories of economic development, created on the basis of the neoliberal approach, have not assumed intervention of public authorities - the authorities had only the task of creating appropriate legislation for the free development of economic activities. In recent decades, theories more closely relating to John Keynes' (1936) doctrine are more frequent. They indicate many factors affecting the economic development of the regions, among others: they emphasize the importance of export activity - economic base theory (North, 1955; Rittenbruch, 1968), strengthening or creating new growth poles - growth poles and geographical growth centers (Perroux, 1964; Hirschman, 1958), regional growth centers - core and periphery model (Friedman, 1963), all innovative activities of entrepreneurs product-cycle theory (Vernon, 1966), regional project offices establishing to develop the investment potential and effective portfolio management (Kostiukevych et al., 2020), new technologies and new industrial branches (Castells, 1994), business environment institutions, research centers (Florida, 2000), social phenomena and cultural norms (Myrdal, 1957). They also assume the need for intervention by public authorities. This is the result of accumulation of inter-regional differences. According to these assumptions, highly developed regions are 
becoming increasingly economically viable, and in less developed areas (peripheries) the problem areas are getting deeper. This is why some theories postulate various administrative actions, such as improving the skills of the workforce, investing in infrastructure, promoting exports, building institutions to support entrepreneurship development, disseminating innovative management and technology, and innovating (Grosse, 2007).

Many economists recognize the dominant role of technological innovation for economic development (Samuelson \& Nordhaus, 2000; Zumbusch \& Scherer, 2013). Schumpeter (1960) indicated innovation as a concept in which in order to maintain a high competitive position in the market, companies have to display a high level innovation. Also, many regional development theories recognize this factor as key to the development of the region. Technological change can improve economic efficiency, provide competitive advantage in external markets, and modernize economic structure in regions. Therefore, the most important element of a regional economy is knowledge and technological development. On this basis, Florida (2000) developed the learning region theory, which maintains constant innovation and adaptability to changing market conditions. Learning involves the interaction and cooperation of different actors by creating conditions conducive to the development of knowledge and innovation. On the other hand, public authorities should stimulate innovation and market adaptation, i.e., the development of science and research, the improvement of human resources and the supply of enterprises with modern technology (Florida, 2000).

Innovation is the result of an interactive process in which the market (individuals, organizations, e.g. firms) and non-market institutions (e.g. universities) are engaged to search for the field in which to develop. Many economists encourage public authorities to support technological development. Most often they postulate the creation of a regional innovation system (RIS) (Strzelecki, 2008). Regional authorities have a significant role in this process, supporting the development of general and specialized infrastructure, supporting research and development, creating effective measures to stimulate business innovation, and creating institutionalized support forms (regional innovation centers and research parks). In particular, innovative start-ups are an important driver of economic growth (Mueller, 2007). Similarly, Stam and Wennberg (2009) show that R\&D matters for a limited but important set of new high-tech and high-growth firms, which are key in innovation and entrepreneurship policies.

The newest concept of regional development is the smart specialization strategy (Foray et al., 2009). Intelligent specialization is primarily to strengthen the potential for research and development at the regional level. The concept refers to the endogenous theory of regional development, according to which regional development is based on the accumulation of the factors of production and knowledge.

Many economists (Koellinger, 2008; Williams \& McGuire, 2010; Audretsch et al., 2017) emphasize the importance of a suitable social and institutional climate for innovative entrepreneurship. A catalog of innovative milieus or environments for entrepreneurship is worth mentioning. First and foremost, it covers the region's research and research resources, in particular universities, and a highly qualified workforce, primarily experienced managers. The lack of skilled employees can create essential obstacles for entrepreneurship development influencing its performance (Bilan et al., 2020; Smolarek \& Sułkowski, 2020). Another important element of the innovation environment is professional public administration and a high level of technical infrastructure, especially telecommunications, in the region. The appropriate infrastructure is crucial for the growth of certain industries, vital for the regional development, and regional authorities support has high importance in this regard (Adair \& Adaskou, 2018; Dung et al., 2018). The next element is a high standard of living conditions, especially the quality of educational, cultural and entertainment institutions and the cleanliness and accessibility of the natural environment (Vila et al., 2015). It is also important to analyse the socio-economic relevance of social capital in the regions. Its resources are seen 
as an element of regional development (Malecki, 2012). Some researchers suggest that social capital is positively closely linked to entrepreneurship (Gedajlovic et al., 2013; McKeever et al., 2014; Zainol et al., 2018) and innovations (Miguélez et al., 2011; Echebarria \& Barrutia 2013; Hauser et al., 2007; Laursen et al., 2012).

To summarize this part of the argumentation, economic concepts of regional development treat regions as something given, as a tool for policy of development. There is a scarcity of theoretical economic reflection on the essence of the region and the social processes involved in this phenomenon and influencing the effectiveness of political and economic actions.

\subsection{Peripheral region in sociological perspective}

There are at least three main groups of meanings of the region: 1) recalling the region as a tool of research, 2) pointing at the region as a tool of policy, and 3) treating the region as the object of cognition (Rykiel, 2001). In the first meaning region is used mainly by geographic sciences, the second one dominates in policy-making everyday practice, while the third relates to a subnational level of social organization. The three meanings of the region represent the evolution of the concept from a specific area separated on the basis of physical characteristics, through supplementation with economic characteristics (Regional Science) and social functions, up to cultural dimensions within a humanistic approach (HampdenTurner \& Trompenaars, 1997; Sagan, 2003). This final, contemporary meaning is well presented in the sociological definition of the region as a spatial-social entity spontaneously emerging in the long historical process, with a specific culture and consciousness of a "regional us" determining social actions (Pred, 1984; Jałowiecki \& Szczepański, 2002; Paasi, 2009; Paasi \& Metzger, 2016).

The historic aspect of the region is crucial for the concept of regional culture, however confusing in the context of administrative borders of the regions, which rarely reflect historic structures but almost always are a consequence of current political interests. In other words, the region is one of these social spaces where structures of long-term duration (Braudel, 1960) are confronted with usually short-term goal-oriented actual economic and political actions. One of most significant examples of such confrontation is the EU's regional policyunderstanding the region as a territory in which the population has an identity based on specific characteristics and which wants to develop this identity to stimulate cultural, social and economic progress (European Charter of Local Self-Government, 1985; Paasi, 2009). For the EU's regional policy one needs units with well-recognized administrative borders (despite differences in each state's administration system all are statistically treated as NUTS II) that are tools of convergence within the EU.

In the past the EU's cohesion policy has only marginally taken into account the objectives related to the development of innovative and modern technologies (Grosse, 2007). The change in cohesion policy has been seen since 2007. Among the objectives of the Lisbon Strategy for Growth and Jobs (European Parliament, 2000) are two main objectives: to stimulate the innovation of the European economy and to fight for growth in employment. An important aspect of the growth and employment strategy is to stimulate innovation at regional and local level (Lewandowska et al., 2019). Programs targeted at the creation of regional innovation strategies (RIS) are examples of activities pursuing the above-mentioned priorities (European Commission, 2007). A novel approach of the EU towards regional policy is a smart specialization. The idea of the development policy based on innovation and entrepreneurship focused on specific areas of specialisation is the direction set for the member states by the European Commission for the period 2014-2020. The basic assumption behind smart specialisation is to increase innovativeness and competitiveness of regions on the basis 
of their endogenous potential and the industries that are already functioning there (European Commission, 2010). Smart growth is necessary to be able to compete on the global market (European Commission, 2014).

From a sociological point of view there is another consequence of the EU's regional policy that is called "neo-regionalism." We assign this process mainly to the EU's regional policy because of the funds that support regional governments in their region-oriented actions. This process is brings about much of the reinventing of regions on the basis of administrative units, where social, political and economic elites introduce a "new tradition" of the region the phenomenon being part of the reflexivity typical for the late modern age (Giddens, 1991). If regionalism consists of long-term duration structures resulting in regional identity and tendencies for self-governing, then neo-regionalism consists of administrative units that need regional identity for proper implementation of regional policy objectives, and therefore need to invent new tradition (Paasi, 2009; Breuer, 2011). However, this process never takes place in a social vacuum - according to F. Braudel (1960), there are always structures of long-term duration.

Braudel's concept of long-term duration finds articulation in the theory of a worldeconomy (Wallerstein, 2006), that stresses a relation between core and periphery structures, such as states or regions. According to Wallerstein, this relation is based on historical (longterm) foundations of quasi-monopolization of production processes. These foundations tend to be quite stable, because "there have always been new core-like processes to replace those which become more competitive and then move out of the states in which they were originally located" (Wallerstein, 2006: p. 29). We find this theory especially useful in innovativeness analysis in the regional dimension, because of three main reasons: a) the EU's regional policy recognizes regions as tools of economic progress, b) to minimalize differences between core and peripheral regions of the EU in the meaning of convergence, c) mainly by financial support for entrepreneurship and innovativeness in peripheral regions.

However, Wallerstein's theory of a core-periphery relation between regions and states within a world-economy states that the asymmetry is permanent, or at least of a long-term duration. Therefore, it is not only a matter of the number of enterprises or innovations (quantitative aspect, sometimes misleading in statistics), but of the quality of them (the qualitative aspect, often omitted in statistics), probably in the first place - the higher quality the more core-like entrepreneurship or innovation.

In other words, we assumed that there are at least three main "ideal" types of SME innovation strategy. The first is "creation", when innovation becomes the core of the functioning of the firm (SMEs are interested in constant original innovations, based on internal $R \& D$ and/or tight cooperation with external R\&D institutions, with the full use of external support of the institutional system). Such SMEs are described as "creators". The second is "interaction", when the innovation is not the main paradigm for the enterprise (but is important enough to be developed and supported by occasional SME cooperation with external $\mathrm{R} \& \mathrm{D}$ institutions and the utilitarian approach towards public financing of the innovation). This strategy is characteristic for SMEs described as "pragmatists". Finally, there is "reaction", when innovations are not the consequence of systematic reflection, but they are rather a reaction to new situation, and therefore much more random (there is no originality in innovation - the novelty of products/services/processes applies only to enterprise level; the cooperation with R\&D institutions is from case to case, usually as the argument for additional public financial support). This strategy is characteristic for "imitators".

The basis of this typology is that in the matters of innovation in Wallerstein's core there is a quantitative and qualitative excess of "creators" while in Wallerstein's periphery dominate "imitators". The official definition of "innovation" is so wide that statistics such as the Regional Innovation Scoreboard may give a misleading impression when comparing 
different entities - such as regions (both within one state or between states). More importantly, knowledge and understanding of the approach(es) towards innovations among enterprises determine regional level innovativeness and describe the effectiveness of the institutional support system.

\section{Methodological approach}

In our opinion the Podkarpackie region meets the conditions of a peripheral region for a few important reasons: a) it is an administrative region without any regional traditions (Stopa, 2008), b) its regional elites with "neo-regional" aspirations strengthened by the EU's funds (Stopa, 2008), c) it is among less developed regions in Poland which finds consequences in modernization policy (Crescenzi \& Rodríguez-Pose, 2012), d) economics are characterized by a high share of unprofitable and fragmented agriculture and complete dominance of SMEs (Central Statistical Office of Poland). However, at the very same time, the region is among those with the highest rates of innovativeness in Poland (Regional Innovation Scoreboard, 2016), though considering only the number of innovations implemented without any distinctions due to the type of the innovations. This divergence between official statistics and theoretical remarks on the conditions for the development of innovation provided an impetus for research into the determinants of innovation in SMEs.

Empirical conclusions presented in this article come from various research conducted at different periods of time, but they all have been complete in the Podkarpackie region and with representatives of SMEs or institutions in the SME environment. It started as "Monitoring and evaluation of RIS in the Podkarpackie region" (system project: "Enhancing the institutional system of implementation of the Regional Innovation Strategy for the years 2007-2013 in the Podkarpackie region") in 2010-2014. There were four official waves of research in "Monitoring and Evaluation of RIS in the Podkarpackie region" carried out in 2011, 2012, 2013, and 2014. Each of them consisted of quantitative Computer Assisted Telephone Interviews conducted with a representative weighted sample of enterprises (approximately 404 interviews per year) and qualitative in-depth interviews with "innovation leaders" in the region (from 15 up to 22 interviews per year). This project was then continued as "The study of the impact of investments in innovation on the competitiveness of the SME sector in the Podkarpackie voivodship" in 2014-2016. In 2014, during "The study of the impact of investments in innovation on the competitiveness of the SME sector in the Podkarpackie voivodship" there was one quantitative study with 820 (419 innovative firms and 401 non-innovative firms) Computer Assisted Telephone Interviews among representative sample of the SME sector in the region, and 16 qualitative IDIs with innovative SMEs, business environment institutions (BEI), research and development (R\&D) entities and local government (LG).

The paper presents the results of analysis of the data (from CATI) only for those enterprises that introduced at least one innovation in the period 2004-2011. Therefore, the maximum error for interpretations and conclusions is 5\% (still at confidence level 0.95 and 0.50 fraction - unknown distribution of characteristics).

The "innovation leader" is understood as a company occupying a top position in the rankings of innovation, which had introduced at least one product innovation (a new or significantly improved product) or process innovation (a new or significantly improved process). These innovations had to be new, at least for the company that implemented them. The selection of the sample took into account the winners of the "Innovator of the Podkarpackie region" competition.

In this study, the main statistical test for relationships and dependencies was the chisquare test of independence. The analysis for variance ( $\mathrm{H}$ Kruskal-Wallis' test for $\mathrm{k}$ 
independent samples) procedure was implemented to assess the statistical significance differences between averages in innovation quantity and quality due to different factors among enterprises.

\section{Conducting research and results}

The general description of innovativeness of SMEs in the Podkarpackie region is based on research results presented in the series of "The studies on innovation of the Podkarpackie region". Approximately one third of researched SMEs in the Podkarpackie region had implemented innovations, mainly product innovations, in the years 2011-2014. What is even more important, quite the same number of them planned to implement innovation in the year after. The probability of consequent, year to year, implementation of innovations grew among these enterprises that implemented at least one innovation.

\subsection{The quantity scale of innovation}

Analysis concentrated on factors determining innovativeness which showed that the larger SMEs (number of employees), the more profitable (the scale of investment) and the more active on external markets (the territorial range and scale of activity), the more numerous innovations had been implemented (Lewandowska \& Stopa, 2016, 2019). The dependent variables in this research were engagement in research and development (scale from "only internal R+D", through "both an internal and external research", to "only external $\mathrm{R}+\mathrm{D}$ ", and additionally "none"), a cooperation index (as number of parties in research and development cooperation - for 32 enterprises that declared such cooperation), and an institutional support index (as the number of institutions supporting innovation in the researched enterprises). These variables added up to the readiness for innovation of each enterprise in the study.

The test for statistically significant differences in the quantity scale of innovation resulting from "independent" and "dependent" factors' influence, was based on the H Kruskal-Wallis' test for $\mathrm{k}$ independent samples (due to the chi-square distribution of the quantity scale of innovation). Table 1 shows the $\mathrm{p}$ value of the test for the variables used in this research.

Table 1. P-value of H Kruskal-Wallis' test for k independent samples

\begin{tabular}{|c|c|c|c|}
\hline Hard factors & $\mathrm{p}$ value & Soft factors & $\mathrm{p}$ value \\
\hline range/scale of activities & .000 & engagement in R\&D & .203 \\
\hline value of investment in 2011/2012 & .000 & cooperation index & .154 \\
\hline number of employees in $2011 / 2012$ & .000 & institutional support index & .065 \\
\hline
\end{tabular}

Factors such as engagement in $R \& D$ (own $R \& D$ departments or cooperation with external R\&D institutions), cooperation with clients and partners (private and institutional) and institutional support (the use of financial support) had not affected the number of innovations in SMEs in the Podkarpackie region in a statistically significant way (Lewandowska \& Stopa, 2016, 2019).

The explanation of this tendency is among the biggest obstacles of innovativenessthe representatives of surveyed SMEs regularly pointed out the lack of own funds. This had been quite surprising due to the institutional support system and public funds invested in the EU's programs focused on innovativeness. Simply, the researched SMEs had not used this 
institutional support explaining this reluctance by bureaucratic conditions of public support, the risk of innovation project failure along with the very rigid formal publicly financed project framework and no flexibility in recognition and adoption of innovation projects.

\subsection{The quality scale of innovation}

Further analysis of quality of innovations implemented in researched SMEs in the Podkarpackie region showed that the majority of surveyed representatives of SMEs acknowledged that these innovations had been implemented in other companies before. Therefore, it proved that innovative SMEs in the Podkarpackie voivodship were clearly local in their perspective of functioning and competing. Moreover, these innovations were forced by attempts to catch up rather than to set the pace of the change itself. Further analysis of the quality of innovation included three different aspects: whether the innovation (new/improved product/service or new/improved process) was original or not; who inspired the innovation in the case where it was not original (local, regional, national and foreign enterprises); and who was responsible for final implementation of the innovation (enterprise itself, enterprise in cooperation with other companies, enterprise in cooperation with R\&D institutions, mainly other companies) (Lewandowska \& Stopa, 2016, 2019).

Tables 2 and 3 present the p-value of the test for the factors indicated above for originality of new/improved products/services and processes.

Table 2. P-value of chi-square independence test for originality of new/improved product/services

\begin{tabular}{lclc}
\hline \multicolumn{1}{c}{ Hard factors } & $\mathrm{p}$ value & \multicolumn{1}{c}{ Soft factors } & $\mathrm{p}$ value \\
\hline range/scale of activities & .009 & engagement in R\&D & .040 \\
\hline value of investment in 2011/2012 & .244 & cooperation index & .090 \\
\hline number of employees in 2011/2012 & .096 & institutional support index & .879 \\
\hline
\end{tabular}

Source: author's study based on the results of Computer Assisted Telephone Interviews (CATI).

Table 3. P-value of chi-square independence test for originality of new/improved processes

\begin{tabular}{lclc}
\multicolumn{1}{c}{ Hard factors } & $\mathrm{p}$ value & \multicolumn{1}{c}{ Soft factors } & $\mathrm{p}$ value \\
\hline range/scale of activities & .388 & engagement in R\&D & .155 \\
\hline value of investment in 2011/2012 & .348 & cooperation index & .454 \\
\hline number of employees in 2011/2012 & .814 & institutional support index & .867 \\
\hline
\end{tabular}

Source: author's study based on the results of Computer Assisted Telephone Interviews (CATI).

The engagement in R\&D and the range/scale of activities influenced the originality of product/service innovation. Enterprises that did have their own R\&D section or cooperated with external $R \& D$ institutions and operated on a wider scale than local or regional more often introduced original product/service innovation. Actually, these two factors were the only ones that correlated significantly. What is more, process innovations were independent of any of the indicated factors.

The less cooperation with an R\&D institutional system, the more local was the innovation inspiration - in both cases (products/services: p-value .040 : Kendall's tau-b=-. 140 and processes: $\mathrm{p}$-value .013 : Kendall's tau-b=-.212). 


\subsection{Innovation strategy in different perspectives}

Statistical data from the surveys need more in-depth context for proper interpretation. IDIs with the representatives of the most innovative SMEs in the Podkarpackie region give such perspective. Entrepreneurs understood innovation in a very practical manner innovation had been anything that increased, in any respect, the level of technology used in the SME. It had not been at all, in this perspective, groundbreaking change but very often a slightly modified existing solution, which, however, qualitatively had changed the situation of the company (Lewandowska \& Stopa, 2018).

The small and medium enterprises' perspective reveals a crucial internal contradiction: on one hand innovativeness is the main source of income, but on the other hand it needs great amounts of expenditures that could lead to the risk of bankruptcy due to the perspective of long-term, and more potential than guaranteed, profit from the innovation. Crucial reference points for evaluation of any new ideas in SME perspective were the costs of innovation and potential profit from the innovation. Therefore, these SMEs quite commonly tried to transfer the risks to the client who had become one of the important parties of the innovation process (parties that are often external to the region). Such a strategy allowed them to disperse potential threats and in the same time gain additional financing for innovation. The same criteria of risk had been used by innovation leaders to evaluate public financial support - rigid formal frameworks of the EU projects had been perceived in categories of possible threat to the SMEs existence (in the case of a possible unsuccessful project financed from public sources) (Lewandowska \& Stopa, 2018). Additionally, the representatives of small and medium enterprises perceived the regional system of innovation support as not fully transparent and equal to all participants. In practice, it results in conscious resignation from public financial support and financing the innovation from own sources and along with a client. Therefore, when speaking of "cooperation in innovation", SME representatives concentrated on "no external financial support".

Regional R\&D institutions were focused rather on an educational role because of their dependency and attribution to public universities (all but one have been created at universities). Because of the high costs of research they had been forced to garner as much public financing as possible, therefore they looked for cooperation with SMEs within the EU's programs for innovativeness, but at the very same time they competed for these funds with all other SMEs which they had not cooperated with (Lewandowska \& Stopa, 2018). What was quite typical for interviews with the representatives of $R \& D$ institutions in the Podkarpackie region was that their cooperation in innovation with enterprises was understood as education of future human resources that would trigger further innovativeness. R\&Ds had been perceived by respondents as tools for technological, economic and social development of the region (Lewandowska \& Stopa, 2018).

The most crucial internal contradiction in cooperation of $R \& D$ with firms is the fact that all their infrastructure is built thanks to public financial support, therefore they are unable to use it commercially for at least five years. The opinions these surveyed R\&D representatives on publicly financed projects were quite similar to those formulated by SMEs - external financial support is not as transparent as it should and that competing with public universities and their R\&D units is difficult.

In the case of business environment institutions (BEI), the argument is not as consistent as in the SME and R\&D perspectives. Regional business environment institution (BEI) representatives stressed that innovativeness had not been in the center of their main domain - which had been supporting entrepreneurship in general. Within such an understood goal, BEIs had decided to provide some sophisticated services such as laboratories, 3D printers, advanced measuring machines or machining centers for testing prototypes. 
Entrepreneurship support meant to BEIs the starting point in building new cooperation, as the response to the needs of innovative enterprises. The main goal of such a strategy was to facilitate the innovation process by consulting (due to and in opposition to "unreliable external financial support") (Lewandowska \& Stopa, 2018).

\section{Conclusion}

The debate over entrepreneurship and innovation is everlasting. Little is known on whether company-level evaluation of regional policy has effects, especially in a peripheral region. We have presented a case study of a less developed region under regional development-stimulating entrepreneurship and innovation. Our findings can clarify relations between investment strategies of SMEs and institutional environments that should support SMEs in action and planning. We show the case where both investment strategies SMEs and institutional environments had some incompatibility.

In our opinion such empirical results reflect the innovativeness of small and medium enterprises in a peripheral region, giving an opportunity to portray and analyze more complex processes that stand behind the statistical score of the region. We are convinced that policy, programs and actions concentrated on only one aspect of entrepreneurship and innovativeness are actually doomed to failure unless they take into account regional specificity. If the region is to be a tool for development policy, the latter should include the relation between core and peripheries and its immanent asymmetry. The weakness of a peripheral region lies in the lack of the culture of entrepreneurship in general and innovativeness in detail, which finds consequences in an incompatibility between SMEs investment strategies and the institutional environments that should (at least theoretically) support SMEs in action and planning.

In practice, in peripheral regions SMEs finance their innovativeness by themselves, investing in relatively safe and already confirmed solutions expected by the clients. This means that innovativeness of the SME sector is highly dependent on factors such as the size of the company, the market it acts on and potential core-orientation. In Wallerstein's worldeconomy this is nothing more than just a simple transfer of more competitive processes towards cheaper peripheries. Considering the weakness of peripheries, SMEs actually compete with the supporting institutions of their environments.

Professor Dariusz Wojakowski describes this process as the "Lukasiewicz complex" (in a private conversation): in the 19th century Jan Józef Ignacy Łukasiewicz, a Polish pharmacist and entrepreneur invented the oil lamp, starting the oil industry in Europe. However, this technology was already outdated compared to development of electricity and the lightbulb. It does not mean that this innovation did not change the lives of Europeans but one hundred years later it was completely withdrawn.

There is a need for further research to learn of SME innovation strategy differences and analysis of how SME innovation affects strategy effectiveness is needed. Studies of a similar sample in other regions or countries would serve to consolidate these findings and aid considerations of future directions for research.

\section{Acknowledgement}

This research was performed in the framework of the state budget and European Union funds project. Grant number WND-POKL.08.02.02-18-001/08 «Monitoring and Evaluation of RIS in the Podkarpackie region (system project: „Enhancing the institutional 
system of implementation of the Regional Innovation Strategy for the years 2007-2013 in the Podkarpackie region“) (2009-2014), University of Information Technology and Management (UITM) in Rzeszów.

This project was continued as „The study of the impact of investments in innovation on the competitiveness of the SME sector in the Podkarpackie voivodship" (2014-2016) which was financed from the funds granted to the University of Information Technology and Management as a grant for the maintenance of research potential.

\section{References}

Adair, P., \& Adaskou, M. (2018). The capital structure of mature French SMEs and impact of the great recession: A dynamic panel data analysis (2002-2010). Economics, Management and Sustainability, 3(2), 60-75. https://doi.org/10.14254/jems.2018.3-2.5.

Audretsch, D.B., Obschonka, M., Gosling, S.D., \& Potter, J. (2017). A new perspective on entrepreneurial regions: Linking cultural identity with latent and manifest entrepreneurship. Small Business Economics, 48(3), 681-697. https://doi.org/10.1007/s11187-016-9787-9.

Bilan Y., Mishchuk, H., Roshchyk, I., \& Joshi, O. (2020). Hiring and retaining skilled employees in SMEs: Problems in human resource practices and links with organizational success. Business: Theory and Practice, 21(2), 780-791. https://doi.org/10.3846/btp.2020.12750

Braudel, F. (1960). History and the social sciences: The long duration. American Behavioral Scientist, 3(6), 3-13. https://doi.org/10.1177/000276426000300601.

Breuer, Ch. B. (2011). The regional Puzzle: How regions and encompassed Actors are involved in EU regional policy. European Regions. LIT. VERLAG.

Castells, M. (1996). The rise of the network society: The information age: economy, society, and culture. Wiley-Blackwell.

Crescenzi, R., \& Rodríguez-Pose, A. (2012) Infrastructure and regional growth in the European Union. Papers in Regional Science, 91(3), 487-513. https://doi.org/10.1111/j.1435-5957.2012.00439.x.

Dung, H. C., Thanh, P. T. K., Oanh, D. V., \& Long, N. H. (2018). Local government involvement in small tourism firms investment: The case of Phu Tho Province, Vietnam. Economics and Sociology, 11(2), 97-111. doi:10.14254/2071-789X.2018/11$2 / 7$

Echebarria, C., \& Barrutia, J. M. (2013). Limits of social capital as a driver of innovation: An empirical analysis in the context of European regions. Regional Studies, 47(7), 10011017. https://doi.org/10.1080/00343404.2011.603720

European Charter of Local Self-Government, 1985, ETS No. 122.

European Commission. (2007). Growing Regions, growing Europe: Fourth report on economic and social cohesion. Luxembourg: Office for Official Publications of the European Communities.

European Commission. (2010). Europe 2020 A strategy for smart, sustainable and inclusive growth, Communication from the Commission, Brussels, COM(2010) 2020 final from 3.3.2010.

European Commission. (2014). Sixth report on economic, social and territorial cohesion. Investment for jobs and growth. Promoting development and good governance in EU regions and cities. Luxembourg: Office for Official Publications of the European Union. 
European Parliament. (2000). Resolution on the Special European Council to be held in Lisbon, COM(2000) OJ C 377, 29.12.2000.

Florida, R. (2000). The learning region. In: Z.J. Acs (Eds.), Regional Innovation, Knowledge and Global Change. London: Pinter.

Foray D., David, P. A., \& Hall, B. (2009). Smart Specialisation: The concept. In: Knowledge for Growth: Prospect for Science, Technology and Innovation. EUR 24047, European Union.

Gedajlowic, E., Honig, B., Moore, C.B., Payne, G. T., \& Wright, M. (2013). Social Capital and Entrepreneurship: A Schema and Research Agenda. Entrepreneurship Theory And Practice, 37(3), 455-478. https://doi.org/10.1111/etap.12042.

Giddens, A. (1991). Modernity and Self-identity: Self and Society in the Late Modern Age. Stanford University Press.

Grosse, T.G. (2007). Innowacyjna gospodarka na peryferiach?. Warszawa: Instytut Spraw Publicznych.

Hauser, C., Tappeiner, G., \& Walde, J. (2007). The learning region: The impact of social capital and weak ties on innovation. Regional Studies, 41(1), 75-88. https://doi.org/10.1080/00343400600928368.

Hirschman, A. O. (1958). The strategy of Economic Development. New Haven.

Hampden-Turner, Ch. \& Trompenaars, A. (1997). Riding The Waves of Culture: Understanding Diversity in Global Business. New York: McGraw Hill. 2 edition.

Jałowiecki, B., \& Szczepański, M.S. (2002). Rozwój lokalny i regionalny $w$ perspektywie socjologicznej. Tychy: Śląskie Wydawnictwo Naukowe.

Koellinger, P. (2008). Why are some entrepreneurs more innovative than others?. Small Business Economics, 31(1), 21-37. doi: 10.1007/s11187-008-9107-0.

Kostiukevych, R., Melnyk, L., Krulický, T., Kostiukevych, A., \& Melnyk, L. (2020). A valueoriented approach to portfolio management of regional development projects and their financial support. Journal of International Studies, 13(4), 155-170. doi:10.14254/20718330.2020/13-4/11

Laursen, K., Masciarelli, F., \& Prencipe, A. (2012). Regions matter: How localized social capital affects innovation and external knowledge acquisition. Organization Science, 23(1), 177-193. https://doi.org/10.1287/orsc.1110.0650.

Lewandowska, A., \& Stopa M. (2019). Do SME's innovation strategies influence their effectiveness of innovation? Some evidence from the case of Podkarpackie as peripheral region in Poland. Equilibrium. Quarterly Journal of Economics and Economic Policy, 14(3), 521-536. https://doi.org/10.24136/eq.2019.025

Lewandowska, A. Pater, R., \& Cywiński, Ł. (2019). Determinants of business innovation in the Regional Innovation System context. Policy implications for a less developed $\begin{array}{lllll}\text { region. Studia Regionalne } i \text { Lokalne, } & \text { 1(75), }\end{array}$ https://doi.org/10.7366/1509499517501.

Lewandowska, A., \& Stopa, M. (2018). SME's innovativeness and institutional support system: The local experiences in qualitative perspective. Oeconomia Copernicana. Quarterly Journal, 9(2), 333-351.

Lewandowska, A., \& Stopa, M. (2016). Innovation strategies in SMEs. Some evidence from the case of Podkarpackie, Poland. Modern Management Review, 21,23(4), 147-158.

McKeever, E., Anderson, A., \& Jack, S. (2014). Entrepreneurship and mutuality: Social capital in processes and practices. Entrepreneurship \& Regional Development, 26(5-6), 453-477. https://doi.org/10.1080/08985626.2014.939536.

Malecki, E. J. (2012). Regional social capital: Way it metters. Regional Studies, 46(8), 10231039. doi: 10.1080/00343404.2011.607806. 
Miguélez, E., Moreno, R., \& Artís, M. (2011). Does social capital reinforce technological inputs in the creation of knowledge? Evidence from the Spanish regions. Regional Studies, 45(8), 1019-1038. https://doi.org/10.1080/00343400903241543.

Mueller, P. (2007) Exploiting entrepreneurial opportunities: The impact of entrepreneurship on growth. Small Business Economics, 28 (4), 355-362. https://doi.org/10.1007/s11187006-9035-9.

Myrdal, G. (1957). Economic theory and underdeveloped regions. London: Duckworth.

Paasi, A. (2009). The resurgence of the 'Region' and 'Regional Identity': Theoretical perspectives and empirical observations on regional dynamics in Europe. Review of International Studies, 35(S1), 121-146. https://doi.org/10.1017/S0260210509008456.

Paasi, A., \& Metzger, J. (2017). Foregrounding the region. Regional Studies, 51(1), 19-30. https://doi.org/10.1080/00343404.2016.1239818.

Pred, A. (1984). Place as historically contingent process: Structuration and time-geography of becoming place. Annals of the Association of American Geographers, 74(2), 279-297. https://doi.org/10.1111/j.1467-8306.1984.tb01453.x.

Rykiel, Z. (2001). Krytyka teorii regionu społeczno-ekonomicznego. Białystok: Wyższa Szkoła Finansów i Zarządzania w Białymstoku.

Sagan, I. (2004). Współczesne studia regionalne - teoria i metodologia, a także praktyka. Studia Regionalne i Lokalne, 2(16), 25-39.

Samuelson, P.A., \& Nordhaus W.D. (2000). Ekonomia 2. Warszawa: Wydawnictwo Naukowe PWN.

Schumpeter, J. (1960). Teoria rozwoju gospodarczego. Warszawa: Wydawnictwo Naukowe PWN.

Smolarek, M., \& Sułkowski, Ł. (2020). Job satisfaction among SMEs employees in fibres \& textiles of the CEE countries. Economics and Sociology, 13(2), 181-209.

Stackelberg, K., \& Hahne, U. (1998). Teorie rozwoju regionalnego. In: S. Golinowska (Eds.), Rozwój ekonomiczny regionów. Rynek pracy. Procesy migracyjne Polska, Czechy, Niemcy (Raport IPiSS, z. 16). Warszawa.

Stam, E., \& Wennberg, K. (2009). The roles of R\&D in new firm growth. Small Business Economics, 33(1), 77-89. https://doi.org/10.1007/s11187-009-9183-9.

Stopa, M. (2008). New boundries. Regional consciousness in the Polish Subcarpathian Voivodship. In: D. Wojakowski (Eds.), Borders and Fields, Cultures and Places: Cases from Poland (pp. 31-46), Kraków: NOMOS.

Strzelecki, Z. (2008). Polityka regionalna. In: Z. Strzelecki (Eds.), Gospodarka regionalna i lokalna (pp. 78-120). Warszawa: Wydawnictwo Naukowe PWN.

Treaty of Lisbon, Dz.U. from 2007, C 306, p. 1-271 (OJ C 306).

Vernon, R. (1966). International Investment and International Trade in the Product Cycle. Quarterly Journal of Economics, 80(2), 190-207. https://doi.org/10.2307/1880689.

Vila, L.E., Cabrer, B., \& Pavía, J. M. (2015). On the relationship between knowledge creation and economic performance. Technological \& Economic Development of Economy, 21(4), 539-556. https://doi.org/10.3846/20294913.2013.876687.

Wallerstein, I. (2006). World-Systems Analysis. An Introduction. Durham and London: Duke University Press.

Williams, L.K., \& McGuire, S. (2008). Economic creativity and innovation implementation: the entrepreneurial drivers of growth? Evidence from 63 countries. Small Business Economics, 34(4), 391-412. https://doi.org/10.1007/s11187-008-9145-7.

Zainol, N.R., Al Mamun, A., Bin Ahmad, G., \& Bah Simpong, D. (2018). Human capital and entrepreneurial competencies towards performance of informal microenterprises in Kelantan, Malaysia. Economics and Sociology, 11(4), 31-50. https://doi.org/10.14254/2071-789X.2018/11-4/2. 
Zumbusch, K., \& Scherer, R. (2013). Mobilizing enterprises for regional innovation policies. How to assure an active involvement of located enterprises in regional development. Economics and Sociology, 6(1), 13-27. https://doi.org/10.14254/2071-789X.2013/6-1/2. 